\title{
Autoimmunity increases susceptibility to and mortality from sepsis
}

Isaac J. Jensen ${ }^{1 *}$, Samantha N. Jensen ${ }^{1 *}$, Patrick W. McGonagill², Thomas S. Griffith ${ }^{3}$, Ashutosh K. Mangalam ${ }^{4}$, and Vladimir P. Badovinac ${ }^{5 \%}$

${ }^{1}$ Interdisciplinary Graduate Program in Immunology, University of lowa, lowa City, IA; Department of Pathology, University of lowa, lowa City, IA 2Department of Surgery, University of lowa, lowa City, IA.

${ }^{3}$ Microbiology, Immunology, and Cancer Biology PhD Program, University of Minnesota, Minneapolis, MN; Department of Urology, University of Minnesota, Minneapolis, MN; Center for Immunology, University of Minnesota, Minneapolis, MN; Masonic Cancer Center, University of Minnesota, Minneapolis, MN; Minneapolis VA Health Care System, Minneapolis, MN ${ }^{4}$ Interdisciplinary Graduate Program in Immunology, University of lowa, lowa City, IA; Department of Pathology, University of lowa, lowa City, IA

${ }^{5}$ Interdisciplinary Graduate Program in Immunology, University of lowa, lowa City, IA; Department of Pathology, University of lowa, lowa City, IA; Department of Microbiology and Immunology, University of lowa, lowa City, IA.

${ }^{*}$ Co-first authors: Isaac J. Jensen and Samantha N. Jensen

\%Correspondence: vladimir-badovinac@uiowa.edu

Funding: Authors are supported by grants from the National institutes of Health: 5R01Al114543, 1R35GM134880 to VPB, R01GM115462, 1R35GM140881 to TSG, 5R01Al137075 to AKM, T32AI007511, T32AI007485 to IJJ, T32AI007485, and 1R01Al137075-S1 to SNJ; Veterans Health Administration: I01BX001324 to TSG; University of lowa Environmental Health Sciences Research Center, NIEHS/NIH: P30 ES005605 to AKM 


\section{Summary}

32 Our prior publication detailing how sepsis influences subsequent development of EAE presented a

33 conceptual advance in understanding the post-sepsis chronic immunoparalysis state (Jensen et al.,

34 2020). However, the reverse scenario (autoimmunity prior to sepsis) defines a high-risk patient

35 population whose susceptibility to sepsis remains poorly defined. Herein, we present a retrospective

36 analysis of University of lowa Hospital and Clinics patients demonstrating increased sepsis incidence

37 among MS, relative to non-MS, patients. To interrogate how autoimmune disease influences host

38 susceptibility to sepsis well-established murine models of MS and sepsis, EAE and CLP, respectively,

39 were utilized. EAE, relative to non-EAE, mice were highly susceptible to sepsis-induced mortality with

40 elevated cytokine storms. These results were further recapitulated in LPS and S. pneumoniae sepsis

41 models. This work highlights both the relevance of identifying highly susceptible patient populations and

42 expands the growing body of literature that host immune status at the time of septic insult is a potent

43 mortality determinant. 


\section{Introduction}

Multiple sclerosis (MS) is an autoimmune demyelinating disease of the central nervous system (CNS)

that affects $~ 2.8$ million individuals worldwide, and cases are rising (Fox, 2004; Walton et al., 2020). The symptomology of MS includes (but is not limited to) pain, motor dysfunction, and cognitive dysfunction. The etiology of MS is not well understood, but is thought to stem from a complex interaction of genetic and environmental factors (Dendrou et al., 2015; Freedman et al., 2018). MS is commonly diagnosed between the ages of $20-40$, although underlying subclinical pathogenesis may be present long before diagnosis. MS pathogenesis is mediated by proinflammatory auto-reactive $\mathrm{T}$ cells and other immune cells activated prior to migration into the CNS to promote axonal damage (Fox, 2004). In an attempt to subvert the aberrant immune response to the CNS, immunomodulatory/immunosuppressive drugs are often prescribed to patients with MS with varying degrees of success (Tintore et al., 2019). opportunistic infection (Yong and Kim, 2020). The increased propensity to infection may leave MS patients at an increased risk of sepsis.

Sepsis, a dysregulated host response to infection, impacts 9 people every 6 seconds of which 2 will demonstrate increased susceptibility to subsequent infection or cancer development (Danahy et al., 2019; Hotchkiss et al., 2016; Jensen et al., 2018a; Jensen et al., 2018b). This increased risk for secondary complication leads to a substantial economic burden costing over $\$ 20$ billion annually in the United States alone (CDC, 2020). While mortality due to the cytokine storm has diminished over time due to early intervention, the sepsis mortality rate of $\sim 20 \%$ is still excessive (Dombrovskiy et al., 2007; Gaieski et al., 2013). Mortality from sepsis is in part due the complexity and interconnectedness of the cytokine storm that is composed of both pro- and anti-inflammatory cytokines (Danahy et al., 2016; Delano and Ward, 2016; Jensen et al., 2021), and is further complicated by individual comorbidities 
(Rhee et al., 2017; Rhee et al., 2019). The underlying link between MS and subsequent sepsis is not clear. MS patients are often prescribed one of several immunosuppressant drugs, putting them at greater risk of infection. Indeed, certain disease-modifying therapies for MS pose a greater risk for infection, such as rituximab, compared to others (Luna et al., 2020).

Patients with autoimmune diseases, such as MS, are often treated with immunomodulatory drugs that may increase their susceptibility to infection and sepsis. For example, urinary tract infection (UTI) and respiratory infection, are both a common causes of sepsis (Jeganathan et al., 2017) and complications for MS patients, relative to the general population (Harding et al., 2020; Medeiros Junior et al., 2020). In fact, compared to the general healthy population, individuals with MS are at greater risk of sepsis, sepsis-induced complications, and death due to infection (Capkun et al., 2015). MS patients are also more likely to have a principal diagnosis of infection at their final hospital stay prior to death compared to the general healthy population and individuals with diabetes mellitus (Ernst et al., 2016). Moreover, sepsis was a secondary diagnosis for $51 \%$ of MS patients compared to $36 \%$ and $31 \%$ of diabetes mellitus and general healthy individuals, respectively, during a hospital stay (Ernst et al., 2016) demonstrating that even among autoimmune disease MS patients are at increased risk of developing sepsis. The increased propensity to become septic also extends to military veterans, a population that is skewed toward individuals $>50$ years of age and male (Livingston, 2016), both of which are associated with an increased incidence of sepsis. Lastly, veterans with MS are more likely to be hospitalized and

We previously studied the impact of sepsis on subsequent MS-like disease using the experimental die from infection compared with veterans without MS (Nelson et al., 2015). autoimmune encephalomyelitis (EAE) animal model as a means of conceptually interrogating the immunoparalysis state that occurs after sepsis (Jensen et al., 2020). However, there is a strong need to understand how underlying autoimmune conditions, such as MS, influence susceptibility to sepsis- 
94 induced mortality given the increased incidence in this potentially vulnerable population. Thus, with this

95 Research Advance we affirm the increased incidence of sepsis in MS patient cohorts relative to non-MS

96 patient cohorts and interrogate how autoimmunity as a comorbidity in septic populations influences

97 susceptibility to sepsis-induced mortality utilizing murine models of MS (EAE) sepsis (cecal ligation and

98 puncture [CLP], LPS, and S. pneumoniae).

\section{Results and Discussion}

$101 \quad$ MS patients are more prone to sepsis than the general population

102 Prior literature suggests an increased susceptibility of MS patients to develop sepsis relative to non-MS

103 patient cohorts (Capkun et al., 2015). Therefore, to begin interrogating this potentially interesting

104 interplay, we performed a retrospective analysis of ICU admissions at the University of lowa Hospital

105 and Clinics. This analysis included 211,470 patients admitted between 2008 and 2020, of which there were 22,930 that were septic and 1,180 that had MS (Table 1). Notable features of these patient cohorts included: septic patients tended to be older and male - known risk factors associated with developing sepsis (Rhee et al., 2017; Rhee et al., 2019), while MS patients tended to be female - MS is a known female biased disease (Fox, 2004). There was also a slight increase in the proportion of Caucasian patients among the septic patients. Importantly, MS patients exhibited a significant increase in sepsis

111 incidence $(14.4 \%)$ relative to non-MS patients (10.8\%; Odds ratio: $1.387, \mathrm{p}=0.0001)$. Additionally, while 112 MS patients tended to be female, there was a higher proportion of males among the septic MS patients 113 (35\%) relative to the non-septic MS patients (26\%). Further, septic MS patients also tended to be older $114(64+/-14$ years) than their non-septic MS patient counterparts (56+/-16 years). These data reaffirm both 115 the higher incidence of sepsis in males and with age even within the MS patient cohort. Overall, these 116 data affirm that MS patients have an increased incidence of sepsis relative to non-MS patient cohorts. 
119 Given that MS patients have a higher incidence of sepsis, we sought to understand how having an 120 ongoing autoimmune disease would influence host susceptibility to sepsis. To address this relationship, 121 well-established models of inducible MS-like disease and polymicrobial sepsis, EAE and CLP, 122 respectively, were used. C57BL/6 mice were immunized with $\mathrm{MOG}_{35-55}$ to induce $\mathrm{EAE}$ or left 123 unimmunized (non-EAE). CLP or sham surgery was performed $>35$ days post-immunization and 124 mortality was assessed (Figure 1a). To ensure that mortality was not simply due to ongoing EAE 125 disease, EAE mice were segregated into sham and CLP groups to establish a similar distribution of EAE 126 clinical scores prior to surgery (Figure 1b). Non-EAE mice exhibited some mortality, however, EAE mice 127 had diminished survival relative to non-EAE mice (Figure 1c). Importantly, EAE mice that underwent 128 sham surgery did not have any mortality, consistent with the model system and demonstrating that 129 mortality in EAE with CLP was not due to EAE disease. These data also suggest the presence of CNS 130 autoimmunity increases the host susceptibility to a fatal septic event. Interestingly, there was an 131 observed relationship between the EAE disease score prior to sepsis induction and the likelihood of 132 mortality (Figure 1d,e). Mice with a score of $\leq 2$ had a similar survival rate to naïve CLP mice, whereas 133 all mice with an EAE score $>2$ succumbed to disease (Figure 1e).

135 Auto-immune inflammation, not clinical disease, dictates susceptibility to sepsis

136 The relationship between disease severity and mortality suggests that either the paralysis and 137 associated neurologic damage during EAE is promoting sepsis-induced mortality or differences in the 138 inflammatory response may increase the likelihood of mortality. Indeed, we previously reported that 139 microbially-experienced 'dirty' mice with a high degree of immunologic experience are highly susceptible 140 to sepsis-induced mortality due (in part) to elevations in plasma cytokine concentrations both at a 141 baseline and during the peak ( 12hrs post-induction) of the cytokine storm (Huggins et al., 2019). 142 Similarly, we have also described a relationship between tumor size at the time of sepsis induction and 143 host mortality (Danahy et al., 2019). Thus, to begin teasing apart the roles of the interconnected 
144 phenomena of inflammation and paralysis, mice were immunized at varying times leading up to sepsis

145 induction. This approach establishes a scenario in which disease is subclinical (D5), being established

146 (D15), or fulminant (D25) with ongoing inflammation anticipated in all cohorts (Figure 2a). Clinical

147 disease progression occurred in agreement with these expectations (Figure 2b). All EAE cohorts,

148 however, exhibited profound susceptibility to sepsis-induced mortality, demonstrating that clinical

149 disease and paralysis were not required for sepsis-induced mortality (Figure 2c).

To then address the extent to which EAE, similar to infection and cancer, was altering the severity of the sepsis-induced cytokine storm, plasma was collected prior to and 12hrs post-CLP surgery in D5, D15, and D25 (as well as non-EAE) mice and assessed for IL-6, TNF, IL-1 $\beta$, IFN $\gamma$, IL-10, IL2, and IL-12p70 (Figure 3a). Importantly, while there was a cytokine storm in all CLP cohorts, the magnitude of the cytokine storm was substantially higher in EAE mice relative to the non-EAE mice (Figure 3b-d).

156 Further, EAE mice had a higher baseline expression of many cytokines (Figure 3c,d) recapitulating 157 observations in 'dirty' mice (Huggins et al., 2019). Of particular note was IL-6 which has previously been 158 described as a strong indicator of the severity of the cytokine storm (Ma et al., 2016; Qiao et al., 2018; 159 Quu et al., 2018) and was strongly increased in all EAE groups both prior to and after CLP (Figure 3d).

161 These results then led us to question whether there was a quantitative difference in the magnitude of the 162 cytokine storm between survivor and non-survivor mice at D35 post-EAE induction. Thus, plasma IL-6 163 and IL-10 were interrogated in survivor and non-survivor EAE mice as well as non-EAE mice prior to and $16412 \mathrm{hrs}$ after EAE induction (Figure 3-figure supplement 1). Indeed, non-survivor mice had an elevated 165 cytokine storm while survivor mice had a similar magnitude of the cytokine storm as non-EAE mice. This 166 finding further illustrates the susceptibility of EAE mice to sepsis-induced mortality is through 167 enhancement of the cytokine storm. 
169 EAE mice have increased susceptibility to various models of sepsis induction

170 Given the high susceptibility of EAE mice to fatal CLP-induced sepsis, we sought to extend the

171 applicability of this effect to other models of sepsis induction. Intraperitoneal injection of

172 lipopolysaccharide (LPS) is a well-established model of endotoxemia and sepsis with a highly tunable

173 degree of mortality by modulating the concentration of LPS (Danahy et al., 2016; Dickson and Lehmann,

174 2019). With this system, a dose of LPS that elicits a robust cytokine storm, but does not elicit mortality in

175 unmanipulated (e.g., non-EAE) mice, was interrogated (Huggins et al., 2019). LPS was injected 15 days

176 post-EAE induction on EAE and non-EAE cohorts, and mortality was monitored throughout with plasma

177 IL-6 evaluated prior to and $12 \mathrm{hrs}$ post-LPS injection (Figure 4a). Consistent with prior experiments,

178 EAE mice had a range of disease scores (Figure 4b). Importantly, while non-EAE mice exhibited no

179 mortality, as anticipated, EAE mice exhibited rapid and profound mortality recapitulating the

180 observations with CLP (Figure 4c). The enhanced mortality of EAE mice was attributable to increased

181 IL-6 following LPS injection (Figure 4d), similar to observations with CLP mice. These data demonstrate

182 increased sensitivity to TLR4 stimulation likely contributes to the enhanced mortality among EAE mice.

Next, we examined the impact of having EAE followed by an intranasal Streptococcus pneumoniae (S. pneumonia, and S. pneumoniae models of sepsis have high clinical relevance, as nearly half of all sepsis cases result from this bacterial infection (Brown, 2012). Similar to the LPS endotoxemia model, S. pneumoniae infection in this system does not lead to mortality in unmanipulated mice. It does, however, represent a relevant respiratory infection (Bogaert et al., 2004), which are both a common cause of sepsis (Jeganathan et al., 2017) and a frequent complication among MS patients (Harding et al., 2020). Further host ability to control the infection can be assessed by determining the number of colony forming units (CFUs) in the lungs and plasma cytokines to give an indication of the host ability to mount an inflammatory response and clear infection. Utilizing this system, EAE mice and non-EAE 
controls were intranasally inoculated with S. pneumoniae 15 days post-EAE induction. Plasma IL-6 was evaluated prior to and 12 hrs post-S. pneumoniae infection. Additionally, lung S. pneumoniae CFUs were evaluated in 3 mice from each cohort 3 days after infection while mortality was monitored in the remaining mice (Figure 4e). As before, EAE mice exhibited a range of disease severity prior to infection (Figure 4f) and some mortality subsequent to the insult (Figure 4g), though this mortality was not significantly different from non-EAE control mice. Further, a trending increase in plasma IL-6 was observed from EAE mice 12 hrs post-S. pneumoniae infection (Figure 4h), in agreement with the prior findings of an elevated inflammatory response in EAE mice challenged with either CLP or LPS. Interestingly, EAE mice also had reduced control of $S$. pneumoniae infection 3 days post-infection, relative to non-EAE mice (Figure 4i). These data indicates that despite enhanced inflammation, EAE

Cumulatively, these findings indicate that MS patients are at a higher risk of developing sepsis and ongoing autoimmune reactions lay the groundwork for an exacerbated inflammatory response during septic insult that in turn increases the risk of mortality. This conclusion is relevant to both the identification and management of patient populations that are likely to become septic and at high risk of 213 mortality in the event they become septic. Future work should interrogate the utility of intervention 214 strategies in promoting survival of sepsis and assessments of intervention strategies should account for 215 these highly relevant comorbidities in determining efficacy. Importantly, patients with autoimmunity tend 216 be on immunosuppressive regimens (Tintore et al., 2019; Yong and Kim, 2020), while it is yet unclear 217 what the net result of these interventions are on the development of sepsis, these immunosuppressive 218 regimens will undoubtedly be pertinent to the management of the cytokine storm. 
Alternately, it is also relevant to consider the consequences for a patient with autoimmunity who survives a septic insult. This notion is highly related to our previous findings, wherein we observed sepsisinduced immunoparalysis ablated the subsequent development of EAE through the numeric reduction in naïve autoantigen specific CD4 T cells (Jensen et al., 2020). Indeed, sepsis similarly reduces the number and function effector and memory T cells (Cabrera-Perez et al., 2014; Danahy et al., 2017; Duong et al., 2014; Martin et al., 2020; Sjaastad et al., 2020b). Therefore, it is plausible for those individuals that survive to experience a reduction in their autoimmune disease symptoms. Contrastingly, sepsis may also reduce the capacity of suppressor cell populations to mediate their activity and lead to disease exacerbation (Cavassani et al., 2010; Scumpia et al., 2006; Sharma et al., 2015). There are likely multiple complicating factors that dictate whether any such benefit or detriment arises, including the stage of autoimmune disease progression. Such interrogation may lead to enhanced understanding of the sepsis-induced immunoparalysis state or even future therapeutic intervention for MS and autoimmune disease patients. enhancement in mortality among EAE mice. This finding suggests individuals with subclinical or newly developing autoimmunity may be at risk for increased mortality from sepsis. This possibility may be problematic for delineating patient populations with high susceptibility to sepsis-induced mortality as it may not be a recognized complicating factor. Thus, enhanced susceptibility of patient populations to sepsis-induced mortality may be better understood as a result of active inflammatory responses prior to septic insult rather than highly specific comorbidities such as autoimmunity or cancer. These are highly relevant notions when seeking to promote survival and develop future therapeutics. 


\section{Figure Legends}

Figure 1: EAE mice have increased susceptibility to sepsis-induced mortality. A) Experimental Design: C57BL/6 mice were immunized with $\mathrm{MOG}_{35-55}$ to induce $\mathrm{EAE}$. EAE mice underwent either sham or CLP 35 days after EAE induction followed by assessment of mortality, age matched non-immunized (non-EAE) underwent CLP surgery at the same time. (B) EAE clinical scores of mice prior to either sham or CLP surgery. (C) Kaplan-Meier survival curves of EAE mice that underwent sham (black closed circle) or CLP (red semi-circle) surgery and non-EAE mice that underwent CLP surgery (red closed circle with black outline). (D) EAE clinical scores prior to surgery of EAE mice that either succumbed to or survived the septic insult. (E) Kaplan-Meier survival curves of EAE mice that underwent sham (black circle), had an EAE score $\leq 2$ prior to CLP (white circle with red outline), or had an EAE score $>2$ prior to CLP (red closed circle with red outline) surgery and non-EAE mice that underwent CLP surgery (red closed circle with black outline). Data are cumulative of 2 independent experiments with 7-21 mice per

Figure 2: Increased susceptibility of EAE mice to sepsis is independent of disease onset. A) prior to either sham or CLP surgery, age matched non-immunized (non-EAE) underwent CLP surgery at the same time. Mortality was monitored in all cohorts. (B) EAE clinical scores of mice that were induced for EAE at -25, -15, -5 prior to either sham or sepsis surgery. (C) Kaplan-Meier survival curves of day 25 EAE mice that underwent sham surgery (black circle), non-EAE mice that underwent sepsis surgery (red circle with black outline), and day -25 (red circle with red outline), day -15 (red semi-circle), and day -5 (white circle with red outline) EAE mice that underwent CLP. Data are cumulative of 2 independent experiments with 5-31 mice per group. Error bars represent standard error of the mean. ${ }^{*}=p-v a l u e<0.05$. 


\section{Figure 3: EAE mice have increased inflammation prior to and following sepsis induction. A)}

Experimental Design: C57BL/6 mice were immunized with $\mathrm{MOG}_{35-55}$ to induce $\mathrm{EAE}$ at day $-25,-15$, or -5

prior to CLP surgery, age matched non-immunized (non-EAE) underwent CLP surgery at the same time.

Plasma was collected prior to surgery and 12 hrs post-surgery. (B) Heatmap of normalized plasma IL-6, TNF, IL-1 $\beta$, IFN $\gamma$, IL-10, IL-2, and IL-12p70 concentrations in non-EAE, D5 EAE, D15 EAE, and D25

EAE mice prior to and 12 hrs post-CLP surgery. (C) Radar plots of plasma IL-6, TNF, IL-1 $\beta$, IFN $\gamma$, IL-10, non-EAE (red circle with black outline), D5 EAE (white circle with red outline), D15 EAE (red semicircle), and D25 EAE (red circle with red outline) mice. Grey dashed lines indicate the upper (ULOD) and lower (LLOD) limits of detection for the multiplex assay. Samples are combined from 2 independent experiments run on a single multiplex assay with 5-10 mice per group. Error bars represent standard error of the mean. ${ }^{*}=p$-value $<0.05$.

Figure 4: EAE mice have increased susceptibility to multiple sepsis models. A) Experimental Design: C57BL/6 mice were immunized with $\mathrm{MOG}_{35-55}$ to induce $\mathrm{EAE} 15$ days prior to intraperitoneal LPS injection, age matched non-immunized (non-EAE) received identical injections. Plasma was collected prior to and $12 \mathrm{hrs}$ post-LPS injection. Cohorts were monitored for survival. (B) EAE disease scores prior to LPS injection of EAE mice. (C) Kaplan-Meier survival curves for non-EAE and D15 EAE mice following LPS injection. (D) Plasma IL-6 prior to and 12 hrs post-LPS injection in non-EAE (red circle with black outline) and D15 EAE (red semi-circle). Grey dashed lines indicate the upper (ULOD) and lower (LLOD) limits of detection for IL-6 ELISA. (E) Experimental design: C57BL/6 mice were immunized with $\mathrm{MOG}_{35-55}$ to induce EAE 15 days prior to intranasal S. pneumoniae infection, age matched non-immunized (non-EAE) received identical infections. Plasma was collected prior to and 12 
294 hrs post-LPS injection. 3 mice from each cohort were used for determining lung CFU at 3 days post295 infection. Remaining mice in each cohort were monitored for survival. (F) EAE disease scores prior to $S$. 296 pneumoniae infection of EAE mice. (G) Kaplan-Meier survival curves for non-EAE and D15 EAE mice 297 following S. pneumoniae infection. (H) Plasma IL-6 prior to and 12hrs post- S. pneumoniae infection in 298 non-EAE (red circle with black outline) and D15 EAE (red semi-circle). Grey dashed line indicates the 299 lower (LLOD) limits of detection for IL-6 ELISA. (I) S. pneumoniae CFU per gram of lung tissue 3 days 300 after intranasal infection of non-EAE and D15 EAE mice. Dashed line indicates the limit of detection 301 (LOD). Data are from a single experiment with 9-12 mice per group. Error bars represent standard error 302 of the mean. ${ }^{*}=\mathrm{p}$-value $<0.05$

Figure 3-figure supplement 1: Mortality in EAE mice is associated with elevated inflammation.

305 C57BL/6 mice were immunized with $\mathrm{MOG}_{35-55}$ to induce EAE. EAE and age matched non-immunized 306 (non-EAE) mice underwent CLP 35 days after EAE induction. Plasma cytokines were assessed prior to 307 and $12 \mathrm{hrs}$ post-CLP surgery in non-EAE, EAE mice that survived CLP-induced sepsis, and EAE mice 308 that succumbed to CLP-induced sepsis. Plasma IL-6 (A, B) and IL-10 (C, D) prior to (A, C) and 12 hrs 309 post- (B, D) CLP surgery in non-EAE, EAE mice that survived CLP-induced sepsis, and EAE mice that 310 succumbed to CLP-induced sepsis. Grey dashed lines indicate the upper (ULOD) and lower (LLOD)

311 limits of detection for the respective ELISA plate. Samples are combined from 2 independent 312 experiments run on single ELISA plates with 5-8 mice per group. Error bars represent standard error of 313 the mean. * $=$ p-value $<0.05$.

\section{$315 \quad$ Acknowledgements}

316 We thank members of our laboratories and the lab of Dr. Karandikar for technical assistance and helpful 317 discussions. 


\section{References}

320 Bogaert, D., de Groot, R., and Hermans, P.W.M. (2004). Streptococcus pneumoniae colonisation: the key 321 to pneumococcal disease. The Lancet Infectious Diseases 4, 144-154.

322 Brown, J.S. (2012). Community-acquired pneumonia. Clin Med (Northfield II) 12, 538-543.

323 Cabrera-Perez, J., Condotta, S.A., Badovinac, V.P., and Griffith, T.S. (2014). Impact of sepsis on CD4 T 324 cell immunity. J Leukoc Biol 96, 767-777.

325 Capkun, G., Dahlke, F., Lahoz, R., Nordstrom, B., Tilson, H.H., Cutter, G., Bischof, D., Moore, A., 326 Simeone, J., Fraeman, K., et al. (2015). Mortality and comorbidities in patients with multiple sclerosis 327 compared with a population without multiple sclerosis: An observational study using the US Department of 328 Defense administrative claims database. Multiple Sclerosis and Related Disorders 4, 546-554.

329 Cavassani, K.A., Carson, W.F., IV, Moreira, A.P., Wen, H., Schaller, M.A., Ishii, M., Lindell, D.M., Dou, Y., 330 Lukacs, N.W., Keshamouni, V.G., et al. (2010). The post sepsis-induced expansion and enhanced function 331 of regulatory T cells create an environment to potentiate tumor growth. Blood 115, 4403-4411.

332 CDC (2020). Sepsis: Data \& Reports (https://www.cdc.gov/sepsis/datareports/index.html: CDC).

333 Danahy, D.B., Anthony, S.M., Jensen, I.J., Hartwig, S.M., Shan, Q., Xue, H.-H., Harty, J.T., Griffith, T.S., 334 and Badovinac, V.P. (2017). Polymicrobial sepsis impairs bystander recruitment of effector cells to infected 335 skin despite optimal sensing and alarming function of skin resident memory CD8 T cells. PLoS Pathog 13, 336 e1006569.

337 Danahy, D.B., Kurup, S.P., Winborn, C.S., Jensen, I.J., Harty, J.T., Griffith, T.S., and Badovinac, V.P. 338 (2019). Sepsis-Induced State of Immunoparalysis Is Defined by Diminished CD8 T Cell-Mediated 339 Antitumor Immunity. J Immunol 203, 725-735.

340 Danahy, D.B., Strother, R.K., Badovinac, V.P., and Griffith, T.S. (2016). Clinical and Experimental Sepsis 341 Impairs CD8 T-Cell-Mediated Immunity. Crit Rev Immunol 36, 57-74. 
342 Delano, M.J., and Ward, P.A. (2016). The immune system's role in sepsis progression, resolution, and 343 long-term outcome. Immunol Rev 274, 330-353.

344 Dendrou, C.A., Fugger, L., and Friese, M.A. (2015). Immunopathology of multiple sclerosis. Nature 345 Reviews Immunology 15, 545-558.

346 Dickson, K., and Lehmann, C. (2019). Inflammatory Response to Different Toxins in Experimental Sepsis 347 Models. Int J Mol Sci 20, 4341.

348 Dombrovskiy, V.Y., Martin, A.A., Sunderram, J., and Paz, H.L. (2007). Rapid increase in hospitalization 349 and mortality rates for severe sepsis in the United States: A trend analysis from 1993 to $2003^{*}$. Crit Care 350 Med 35, 1244-1250.

351 Duong, S., Condotta, S.A., Rai, D., Martin, M.D., Griffith, T.S., and Badovinac, V.P. (2014). Polymicrobial 352 Sepsis Alters Antigen-Dependent and -Independent Memory CD8 T Cell Functions. J Immunol 192, 3618$353 \quad 3625$.

354 Ernst, F.R., Pocoski, J., Cutter, G., Kaufman, D.W., and Pleimes, D. (2016). Analysis of Diagnoses 355 Associated with Multiple Sclerosis-Related In-Hospital Mortality Using the Premier Hospital Database. 356 International Journal of MS Care 18, 154-161.

357 Fox, E.J. (2004). Immunopathology of multiple sclerosis. Neurology 63, S3-S7.

358 Freedman, S.N., Shahi, S.K., and Mangalam, A.K. (2018). The "Gut Feeling": Breaking Down the Role of 359 Gut Microbiome in Multiple Sclerosis. Neurotherapeutics 15, 109-125.

360 Gaieski, D.F., Edwards, J.M., Kallan, M.J., and Carr, B.G. (2013). Benchmarking the Incidence and 361 Mortality of Severe Sepsis in the United States*. Crit Care Med 41, 1167-1174.

362 Harding, K., Zhu, F., Alotaibi, M., Duggan, T., Tremlett, H., and Kingwell, E. (2020). Multiple cause of death 363 analysis in multiple sclerosis. A population-based study 94, e820-e829.

364 Hotchkiss, R.S., Moldawer, L.L., Opal, S.M., Reinhart, K., Turnbull, I.R., and Vincent, J.-L. (2016). Sepsis 365 and septic shock. Nat Rev Dis Primers 2, 16045. 
Huggins, M.A., Sjaastad, F.V., Pierson, M., Kucaba, T.A., Swanson, W., Staley, C., Weingarden, A.R., Jensen, I.J., Danahy, D.B., Badovinac, V.P., et al. (2019). Microbial Exposure Enhances Immunity to Pathogens Recognized by TLR2 but Increases Susceptibility to Cytokine Storm through TLR4 Sensitization. Cell Rep 28, 1729-1743.e1725.

Jeganathan, N., Yau, S., Ahuja, N., Otu, D., Stein, B., Fogg, L., and Balk, R. (2017). The characteristics and impact of source of infection on sepsis-related ICU outcomes. J Crit Care 41, 170-176.

Jensen, I.J., Jensen, S.N., Sjaastad, F.V., Gibson-Corley, K.N., Dileepan, T., Griffith, T.S., Mangalam, A.K., and Badovinac, V.P. (2020). Sepsis impedes EAE disease development and diminishes autoantigenspecific naïve CD4 T cells. eLife 9, e55800.

Jensen, I.J., McGonagill, P.W., Butler, N.S., Harty, J.T., Griffith, T.S., and Badovinac, V.P. (2021). NK CellDerived IL-10 Supports Host Survival during Sepsis. J Immunol 206, 1171-1180.

Jensen, I.J., Sjaastad, F.V., Griffith, T.S., and Badovinac, V.P. (2018a). Sepsis-Induced T Cell Immunoparalysis: The Ins and Outs of Impaired T Cell Immunity. J Immunol 200, 1543-1553.

Jensen, I.J., Winborn, C.S., Fosdick, M.G., Shao, P., Tremblay, M.M., Shan, Q., Tripathy, S.K., Snyder, C.M., Xue, H.-H., Griffith, T.S., et al. (2018b). Polymicrobial sepsis influences NK-cell-mediated immunity by diminishing NK-cell-intrinsic receptor-mediated effector responses to viral ligands or infections. PLoS Pathog 14, e1007405.

Livingston, G. (2016). Profile of US veterans is changing dramatically as their ranks decline (Pew Research Center: Pew Research Center).

Luna, G., Alping, P., Burman, J., Fink, K., Fogdell-Hahn, A., Gunnarsson, M., Hillert, J., Langer-Gould, A., Lycke, J., Nilsson, P., et al. (2020). Infection Risks Among Patients With Multiple Sclerosis Treated With Fingolimod, Natalizumab, Rituximab, and Injectable Therapies. JAMA Neurology 77, 184-191.

Ma, L., Zhang, H., Yin, Y.-I., Guo, W.-Z., Ma, Y.-q., Wang, Y.-b., Shu, C., and Dong, L.-q. (2016). Role of interleukin- 6 to differentiate sepsis from non-infectious systemic inflammatory response syndrome. Cytokine 88, 126-135. 
391 Mangalam, A., Luckey, D., Basal, E., Jackson, M., Smart, M., Rodriguez, M., and David, C. (2009). HLA392 DQ8 (DQB1*0302)-Restricted Th17 Cells Exacerbate Experimental Autoimmune Encephalomyelitis in 393 HLA-DR3-Transgenic Mice. J Immunol 182, 5131-5139.

394 Martin, M.D., Badovinac, V.P., and Griffith, T.S. (2020). CD4 T Cell Responses and the Sepsis-Induced 395 Immunoparalysis State. Front Immunol 11, 1364.

396 Medeiros Junior, W.L.G.d., Demore, C.C., Mazaro, L.P., de Souza, M.F.N., Parolin, L.F., Melo, L.H., 397 Junior, C.R.W., and Gonçalves, M.V.M. (2020). Urinary tract infection in patients with multiple sclerosis: An 398 overview. Multiple Sclerosis and Related Disorders 46, 102462.

Nelson, R.E., Xie, Y., DuVall, S.L., Butler, J., Kamauu, A.W.C., Knippenberg, K., Schuerch, M., Foskett, N., 400 and LaFleur, J. (2015). Multiple Sclerosis and Risk of Infection-Related Hospitalization and Death in US 401 Veterans. International Journal of MS Care 17, 221-230.

402 Qiao, Z., Wang, W., Yin, L., Luo, P., Greven, J., Horst, K., and Hildebrand, F. (2018). Using IL-6 403 concentrations in the first $24 \mathrm{~h}$ following trauma to predict immunological complications and mortality in 404 trauma patients: a meta-analysis. Eur J Trauma Emerg Surg 44, 679-687.

405 Qiu, X., Zhang, L., Tong, Y., Qu, Y., Wang, H., and Mu, D. (2018). Interleukin-6 for early diagnosis of 406 neonatal sepsis with premature rupture of the membranes: A meta-analysis. Medicine 97, e13146.

407 Rhee, C., Dantes, R., Epstein, L., Murphy, D.J., Seymour, C.W., Iwashyna, T.J., Kadri, S.S., Angus, D.C., 408 Danner, R.L., Fiore, A.E., et al. (2017). Incidence and Trends of Sepsis in US Hospitals Using Clinical vs 409 Claims Data, 2009-2014. JAMA 318, 1241-1249.

410 Rhee, C., Wang, R., Zhang, Z., Fram, D., Kadri, S.S., Klompas, M., and Program, f.t.C.P.E. (2019). 411 Epidemiology of Hospital-Onset Versus Community-Onset Sepsis in U.S. Hospitals and Association With 412 Mortality: A Retrospective Analysis Using Electronic Clinical Data. Crit Care Med 47, 1169-1176.

413 Rudd, K.E., Johnson, S.C., Agesa, K.M., Shackelford, K.A., Tsoi, D., Kievlan, D.R., Colombara, D.V., Ikuta, 414 K.S., Kissoon, N., Finfer, S., et al. (2020). Global, regional, and national sepsis incidence and mortality, 415 1990-2017: analysis for the Global Burden of Disease Study. The Lancet 395, 200-211. 
416 Scumpia, P.O., Delano, M.J., Kelly, K.M., O’Malley, K.A., Efron, P.A., McAuliffe, P.F., Brusko, T., Ungaro,

417 R., Barker, T., Wynn, J.L., et al. (2006). Increased Natural CD4<sup $>+</$ sup $>$ CD25 $<$ sup $>+</$ sup $>$

418 Regulatory T Cells and Their Suppressor Activity Do Not Contribute to Mortality in Murine Polymicrobial

419 Sepsis. J Immunol 177, 7943-7949.

420 Sharma, A., Yang, W.-L., Matsuo, S., and Wang, P. (2015). Differential alterations of tissue T-cell subsets 421 after sepsis. Immunol Lett 168, 41-50.

422 Sjaastad, F.V., Jensen, I.J., Berton, R.R., Badovinac, V.P., and Griffith, T.S. (2020a). Inducing

423 Experimental Polymicrobial Sepsis by Cecal Ligation and Puncture. Curr Protoc Immunol 131, e110.

424 Sjaastad, F.V., Kucaba, T.A., Dileepan, T., Swanson, W., Dail, C., Cabrera-Perez, J., Murphy, K.A., 425 Badovinac, V.P., and Griffith, T.S. (2020b). Polymicrobial Sepsis Impairs Antigen-Specific Memory CD4 T 426 Cell-Mediated Immunity. Front Immunol 11, 1786.

427 Tintore, M., Vidal-Jordana, A., and Sastre-Garriga, J. (2019). Treatment of multiple sclerosis — success 428 from bench to bedside. Nature Reviews Neurology 15, 53-58.

429 Walton, C., King, R., Rechtman, L., Kaye, W., Leray, E., Marrie, R.A., Robertson, N., La Rocca, N., 430 Uitdehaag, B., van der Mei, I., et al. (2020). Rising prevalence of multiple sclerosis worldwide: Insights from 431 the Atlas of MS, third edition. Multiple Sclerosis Journal 26, 1816-1821.

432 Yong, K.P., and Kim, H.J. (2020). Disease modifying therapies and infection risks in multiple sclerosis-a 433 decision-making conundrum. Annals of Translational Medicine 8, 722.

\section{Methods}

\section{Key Resources Table}

\begin{tabular}{|l|l|l|l|l|}
\hline $\begin{array}{l}\text { Reagent type } \\
\text { (species) or } \\
\text { resource }\end{array}$ & Designation & $\begin{array}{l}\text { Source or } \\
\text { reference }\end{array}$ & Identifiers & $\begin{array}{l}\text { Additional } \\
\text { information }\end{array}$ \\
\hline
\end{tabular}




\begin{tabular}{|c|c|c|c|c|}
\hline $\begin{array}{l}\text { strain, strain } \\
\text { background } \\
\text { (Mus musculus) }\end{array}$ & C57BL6/J & $\begin{array}{l}\text { Jackson } \\
\text { Laboratory }\end{array}$ & $\begin{array}{l}\text { Stock } \\
\text { No: 000664 } \\
\text { (RRID:IMSR_JAX } \\
: 000664)\end{array}$ & \\
\hline $\begin{array}{l}\text { peptide, } \\
\text { recombinant } \\
\text { protein }\end{array}$ & $\mathrm{MOG}_{35-55}$ & GenScript & SC1208 & \\
\hline other & $\begin{array}{l}\text { CFA containing } M \text {. } \\
\text { tuberculosis H37Ra }\end{array}$ & Difco & DF3114-33-8 & \\
\hline $\begin{array}{l}\text { peptide, } \\
\text { recombinant } \\
\text { protein }\end{array}$ & $\begin{array}{l}\text { Pertussis toxin from } \\
\text { Bordetella pertussis }\end{array}$ & $\begin{array}{l}\text { Sigma- } \\
\text { Aldrich }\end{array}$ & P7208 & \\
\hline $\begin{array}{l}\text { peptide, } \\
\text { recombinant } \\
\text { protein }\end{array}$ & $\begin{array}{l}\text { LPS } \\
\text { (E. coli O55:B5) }\end{array}$ & Sigma & L2880-25MG & $\begin{array}{l}2.5 \mathrm{mg} / \mathrm{kg} \text { of mouse } \\
\text { body weight }\end{array}$ \\
\hline $\begin{array}{l}\text { strain, strain } \\
\text { background } \\
\text { (Streptococcus } \\
\text { pneumoniae) }\end{array}$ & $\begin{array}{l}\text { Streptococcus } \\
\text { pneumoniae }\end{array}$ & $\begin{array}{l}\text { Wanke-Jellinek } \\
\text { et al. Beneficial } \\
\text { Effects of CpG- } \\
\text { Oligodeoxynucl } \\
\text { eotide } \\
\text { Treatment on } \\
\text { Trauma and } \\
\text { Secondary } \\
\text { Lung Infection. } \\
\text { J Immunol. } \\
\text { 196(2):767-77 } \\
\text { (2016). }\end{array}$ & & $\begin{array}{l}\text { Can be acquired } \\
\text { through lab } \\
\text { contact }\end{array}$ \\
\hline $\begin{array}{l}\text { commercial } \\
\text { assay or kit }\end{array}$ & ProcartaPlex 7-plex & $\begin{array}{l}\text { Thermo- } \\
\text { Fischer }\end{array}$ & $\begin{array}{l}A B \_2575918 \\
A B \_2575931 \\
A B \_2575930 \\
A B \_2575920 \\
A B \_2575919 \\
A B \_2575917 \\
A B \_2575926\end{array}$ & $\begin{array}{l}\text { IL-6, TNF, IL-1 } \beta \text {, } \\
\text { IL-10, IFN } \gamma, \text { IL-2, } \\
\text { IL-12p70 }\end{array}$ \\
\hline
\end{tabular}




\begin{tabular}{|c|c|c|c|c|}
\hline antibody & $\begin{array}{l}\text { IL-10 } \\
\text { (JES5-16E3) }\end{array}$ & Biolegend & AB_315358 & $\begin{array}{l}\text { ELISA } \\
(1 \mu \mathrm{g} / \mathrm{mL})\end{array}$ \\
\hline antibody & $\begin{array}{l}\text { IL-10 } \\
\text { (JES5-2A5) }\end{array}$ & Biolegend & AB_315349 & $\begin{array}{l}\text { ELISA } \\
(2 \mu \mathrm{g} / \mathrm{mL})\end{array}$ \\
\hline antibody & $\begin{array}{l}\text { IL-6 } \\
\text { (MP5-32C11) }\end{array}$ & Biolegend & AB_2233898 & $\begin{array}{l}\text { ELISA } \\
(1 \mu \mathrm{g} / \mathrm{mL})\end{array}$ \\
\hline antibody & $\begin{array}{l}\text { IL-6 } \\
\text { (MP5-20F3) }\end{array}$ & Biolegend & AB_315336 & $\begin{array}{l}\text { ELISA } \\
(2 \mu \mathrm{g} / \mathrm{mL})\end{array}$ \\
\hline $\begin{array}{l}\text { software, } \\
\text { algorithm }\end{array}$ & GraphPad Prism & $\begin{array}{l}\text { GraphPad } \\
\text { Prism } 8\end{array}$ & $\begin{array}{l}\text { Version } 8.4 .2 \\
(464) \\
\text { (RRID:SCR_0 } \\
\text { 02798) }\end{array}$ & \\
\hline
\end{tabular}

$\underline{\text { Retrospective Patient Assessment }}$

438 TriNetX was utilized to query a limited, deidentified dataset of patients at the University of lowa admitted 439 between 2008 and 2020. Adult patients (age 18 to 119 years) who had inpatient encounters were 440 queried. Since this period spans the transition from ICD-9 to ICD-10 coding, the TriNetX software uses 441 algorithms to transform ICD-9 codes to ICD-10 codes. Sepsis patients were queried for all ICD-10 442 codes including "sepsis" in their description utilizing the [or] operator. Multiple sclerosis patients were 443 queried using ICD-10 code group G35 Multiple sclerosis. TriNetX is compliant with the Health Insurance 444 Portability and Accountability Act (HIPAA), the US federal law which protects the privacy and security of 445 healthcare data. TriNetX is certified to the ISO 27001:2013 standard and maintains an Information 446 Security Management System (ISMS) to ensure the protection of the healthcare data it has access to 447 and to meet the requirements of the HIPAA Security Rule. Any data displayed on the TriNetX Platform in 448 aggregate form, or any patient level data provided in a data set generated by the TriNetX Platform, only 449 contains de-identified data as per the de-identification standard defined in Section $\S 164.514(\mathrm{a})$ of the $450 \quad$ HIPAA Privacy Rule. The process by which the data is de-identified is attested to through a formal 
451 determination by a qualified expert as defined in Section $\S 164.514(b)(1)$ of the HIPAA Privacy Rule.

452 TriNetX is supported by the Institute for Clinical and Translational Science at the University of lowa.

453 The Institute for Clinical and Translational Science at the University of lowa is supported by the National

454 Institutes of Health (NIH) Clinical and Translational Science Award (CTSA) program, grant

455 UL1TR002537. The CTSA program is led by the NIH's National Center for Advancing Translational

456 Sciences (NCATS). This publication's contents are solely the responsibility of the authors and do not

457 necessarily represent the official views of the $\mathrm{NIH}$.

Ethics statement

460 Experimental procedures using mice were approved by University of lowa Animal Care and Use

461 Committee under ACURF protocol \#6121915 and \#9101915. The experiments performed followed

462 Office of Laboratory Animal Welfare guidelines and PHS Policy on Humane Care and Use of Laboratory

463 Animals. Cervical dislocation was used as the euthanasia method of all experimental mice.

$\underline{\text { Mice }}$

466 Inbred C57BI/6 (B6; Thy1.2/1.2) were purchased from the National Cancer Institute (Frederick, MD) and 467 maintained in the animal facilities at the University of lowa at the appropriate biosafety level.

$469 \quad$ Cecal ligation and puncture (CLP) model of sepsis induction

470 CLP surgery was performed as previously described (Sjaastad et al., 2020a). Briefly, mice were 471 anesthetized with ketamine/xylazine (University of lowa, Office of Animal Resources), the abdomen was 472 shaved and disinfected with Betadine (Purdue Products), and a midline incision was made. The distal 473 third of the cecum was ligated with Perma-Hand Silk (Ethicon), punctured once using a 25-gauge 474 needle, and a small amount of fecal matter extruded. The cecum was returned to abdomen, the 475 peritoneum was closed with 641G Perma-Hand Silk (Ethicon), and skin sealed using surgical Vetbond 
476 (3M). Following surgery, $1 \mathrm{~mL}$ PBS was administered s.c. to provide post-surgery fluid resuscitation.

477 Lidocaine was administered at the incision site, and flunixin meglumine (Phoenix) was administered for

478 postoperative analgesia. This procedure created a septic state characterized by loss of appetite and

479 body weight, ruffled hair, shivering, diarrhea, and/or periorbital exudates with 0-10\% mortality rate.

$480 \quad$ Sham mice underwent identical surgery excluding cecal ligation and puncture.

$\underline{\text { LPS Endotoxemia induction }}$

483 Mice received a single intraperitoneal injection of LPS-EB from E. coli O55:B5 (2.5 mg/kg body weight; 484 Sigma), as previously described (Huggins et al., 2019).

\section{Streptococcus pneumoniae infection}

Streptococcus was grown in brain heart infusion $(\mathrm{BHI})$ broth then pelleted by centrifugation. Pellet was washed three times and diluted to a target absorbance of 0.1 using PBS, as measured by ABS $_{600}$. Mice were anesthetized with ketamine/xylazine and received $40 \mu \mathrm{L}$ of Streptococcus pneumoniae by

490 intranasal inoculation. Infectious dose was confirmed by plating inoculum $\left(1.5 \times 10^{6} \mathrm{CFU} / \mathrm{mouse}\right)$ on $\mathrm{BHI}$ $491 \quad$ plates.

493 CFU per gram of lung was determined by sacrificing mice and weighing the lungs. Lungs were 494 mechanically homogenized in $1 \mathrm{~mL}$ of PBS. $20 \mu \mathrm{L}$ of homogenate on BHI plates in duplicate.

\section{EAE Disease Induction and Evaluation}

497 EAE was induced and evaluated as shown previously (Mangalam et al., 2009). Briefly, mice were 498 immunized s.c. on day 0 on the left and right flank with $100 \mu \mathrm{g}$ of $\mathrm{MOG}_{35-55}$ emulsified in Complete 499 Freund's Adjuvant followed by $80 \mathrm{ng}$ of pertussis toxin (PTX) i.p. on days 0 and 2. Disease severity was 
scored as follows: 0 , no clinical symptoms; 1 , loss of tail tonicity; 2 , hind limb weakness; 3 , hind limb

501 paralysis; 4 , fore limb weakness; 5 , moribund or death.

Cytokine Analysis

$504 \quad$ Multiplex cytokine analysis was performed via Thermo-Fischer ProcartaPlex 7-plex

505 according to the manufacturer's instructions for plasma cytokine analysis. Multiplex was analyzed on

506 BioRad Bio-Plex (Luminex 200) analyzer in the University of lowa Flow Cytometry core facility.

$508 \quad$ IL-6 and IL-10 ELISAs (ELISA MAX Deluxe Set, Biolegend) were performed according to the 509 manufacturer's instructions.

$511 \quad$ Statistical Analysis

$512 \quad$ Unless stated otherwise data were analyzed using Prism 8 software (GraphPad) using two-tailed

513 Student t-test (for 2 individual groups, if variance was unequal variance then Mann-Whitney U test), one-

514 way ANOVA with Bonferroni post-hoc test (for $>2$ individual groups, if variance was unequal variance

515 then Kruskal-Wallis with Dunn's post-hoc test was used), two-way ANOVA (for multiparametric analysis

516 of 2 or more individual groups, pairing was used for samples that came from the same animal) with a

517 confidence interval of $>95 \%$ to determine significance $\left({ }^{*} p<0.05\right)$. Log-rank (Mantel-Cox) curve

518 comparisons was used to determine significant difference in time to disease EAE disease onset $\left({ }^{*} p<\right.$ 519 0.05). Data are presented as standard error of the mean.

$521 \quad$ Source data

$522 \quad$ Figure 1-source data 1

523 Source data for Figure 1. 
$525 \quad$ Figure 2-source data

526 Source data for Figure 2.

$528 \quad$ Figure 3-source data

$529 \quad$ Source data for Figure 3.

$531 \quad$ Figure 4-source data 1

532 Source data for Figure 4B, C.

533

$534 \quad$ Figure 4-source data 2

535 Source data for Figure 4D.

536

$537 \quad$ Figure 4-source data 3

538 Source data for Figure 4F, G.

539

$540 \quad$ Figure 4-source data 4

$541 \quad$ Source data for Figure $4 \mathrm{H}$.

542

$543 \quad$ Figure 4-source data 5

$544 \quad$ Source data for Figure 4I.

$546 \quad$ Figure 3-figure supplement 1-source data 1

547 Source data for Figure 3-figure supplement 1 A, B.

$549 \quad$ Figure 3-figure supplement 1-source data 2 
bioRxiv preprint doi: https://doi.org/10.1101/2021.07.06.451335; this version posted July 8, 2021. The copyright holder for this preprint (which was not certified by peer review) is the author/funder, who has granted bioRxiv a license to display the preprint in perpetuity. It is made available under aCC-BY 4.0 International license.

550 Source data for Figure 3-figure supplement 1 C, D.

551

$552 \quad$ Table 1-source data

553 Source data for Table 1.

554 


\section{Table 1}

\begin{tabular}{|c|c|c|c|c|c|c|c|}
\hline $\begin{array}{l}\text { Patient } \\
\text { Cohort }\end{array}$ & $\begin{array}{c}\text { All } \\
\text { Inpatient }\end{array}$ & Non-septic & Septic & \% Septic & $\begin{array}{c}\text { Non- } \\
\text { Septic vs } \\
\text { Septic }\end{array}$ & & \\
\hline Total & 211470 & 188540 & 22930 & $10.8 \%$ & & & \\
\hline Age (+/- SD) & $58(+/-20)$ & $57(+/-21)$ & $64(+/-17)$ & & $<0.0001$ & & \\
\hline$\%$ Male & $47 \%$ & $46 \%$ & $53 \%$ & & $<0.0001$ & & \\
\hline$\%$ Caucasian & $87 \%$ & $86 \%$ & $88 \%$ & & $<0.0001$ & & \\
\hline Non-MS & 210290 & 187530 & 22760 & $10.8 \%$ & & & \\
\hline Age (+/- SD) & & $57(+/-21)$ & $64(+/-17)$ & & $<0.0001$ & & \\
\hline$\%$ Male & & $46 \%$ & $53 \%$ & & $<0.0001$ & & \\
\hline$\%$ Caucasian & & $86 \%$ & $89 \%$ & & $<0.0001$ & & \\
\hline MS & 1180 & 1010 & 170 & $14.4 \%$ & & & \\
\hline Age (+/- SD) & & $56(+/-16)$ & $64(+/-14)$ & & $<0.0001$ & & \\
\hline$\%$ Male & & $26 \%$ & $35 \%$ & & 0.0159 & & \\
\hline \% Caucasian & & $89 \%$ & $88 \%$ & & ns & & \\
\hline & & \multicolumn{2}{|c|}{ Age (+/-SD) } & \multicolumn{2}{|c|}{$\%$ Male } & \multicolumn{2}{|c|}{$\%$ Caucasian } \\
\hline \multirow[t]{2}{*}{$\begin{array}{l}\text { Non-MS } \\
\text { vs MS }\end{array}$} & $\begin{array}{c}\text { Sepsis } \\
\text { odds ratio } \\
\end{array}$ & Non-MS & MS & Non-MS & MS & Non-MS & MS \\
\hline & 1.387 & $60.5(+/-5)$ & $60(+/-6)$ & $47 \%$ & $27 \%$ & $86 \%$ & $89 \%$ \\
\hline p-value & 0.0001 & \multicolumn{2}{|c|}{ ns } & \multicolumn{2}{|c|}{$<0.0001$} & \multicolumn{2}{|c|}{0.0121} \\
\hline
\end{tabular}




\section{Figure 1}

bioRxiv preprint doi: https://doi.org/10.1101/2021.07.06.451335; this version posted July 8, 2021. The copyright holder for this preprint (which was not certified by peer review) is the author/funder, who has granted bioRxiv a license to display the preprint in perpetuity. It is made

A

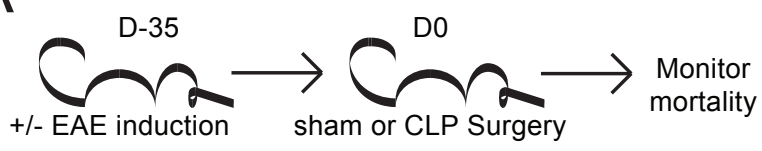

B

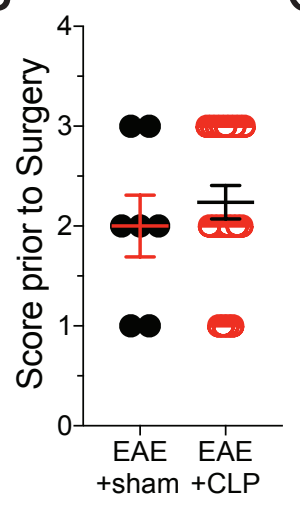

C

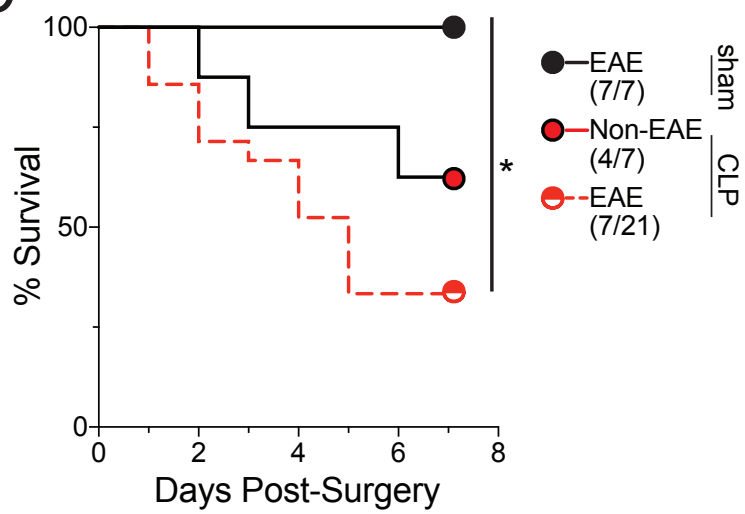

D

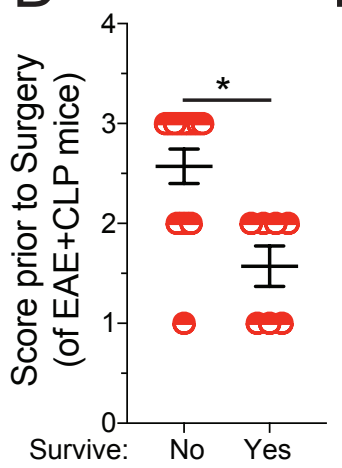

E

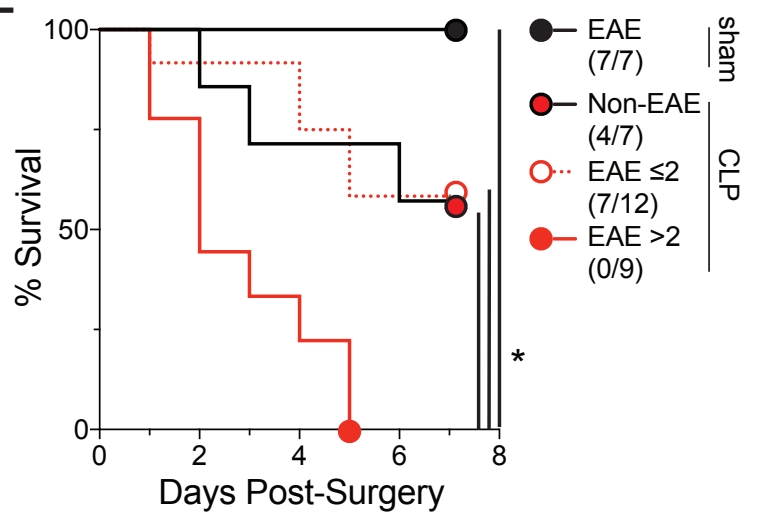


Figure 2

bioRxiv preprint doi: https://doi.org/10.1101/2021.07.06.451335; this version posted July 8, 2021. The copyright holder for this preprint (which was not certified by peer review) is the author/funder, who has granted bioRxiv a license to display the preprint in perpetuity. It is made A available under aCC-BY 4.0 International license.

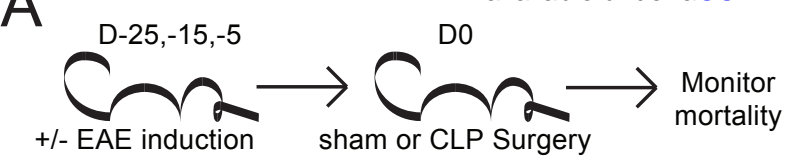

B

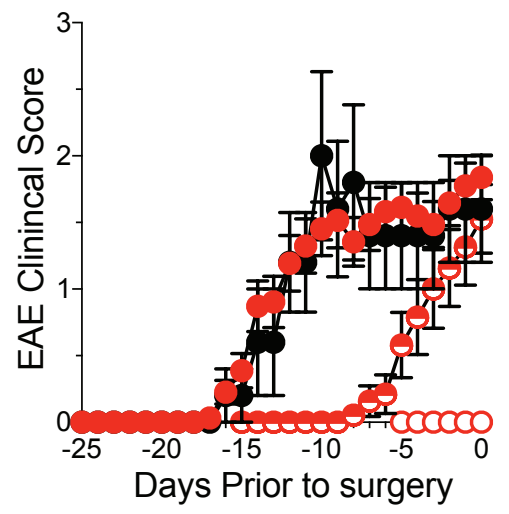

C

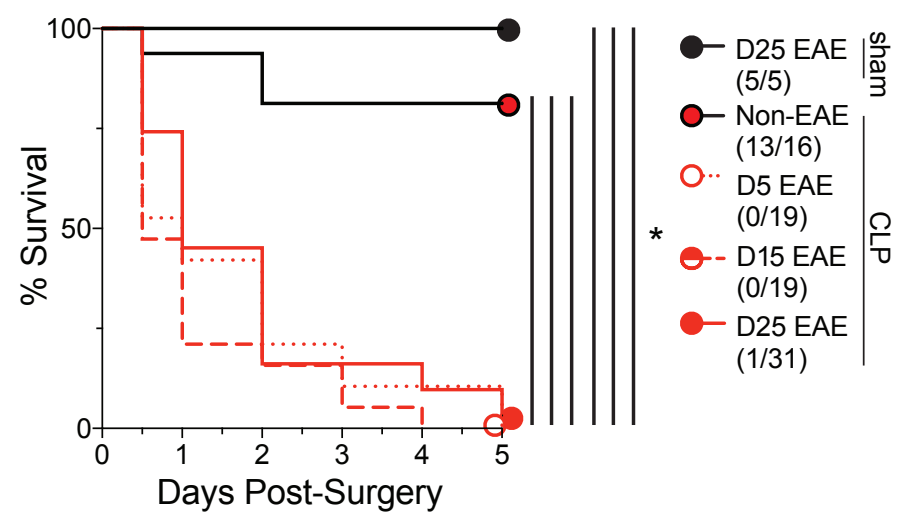


Figure 3

bioRxiv preprint doi: https://doi.org/10.1101/2021.07.06.451335; this version posted July 8, 2021. The copyright holder for this preprint (which was not certified by peer review) is the author/funder, who has granted bioRxiv a license to display the preprint in perpetuity. It is made

A

D-25,-15,-5

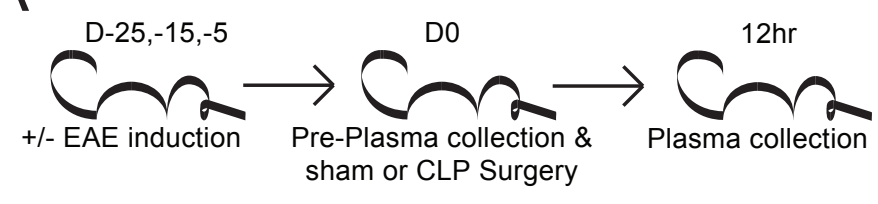

Pre-Plasma collection \& sham or CLP Surgery available underacC-BY 4.0 International license.

C

\section{Pre-Surgery}

IL-6

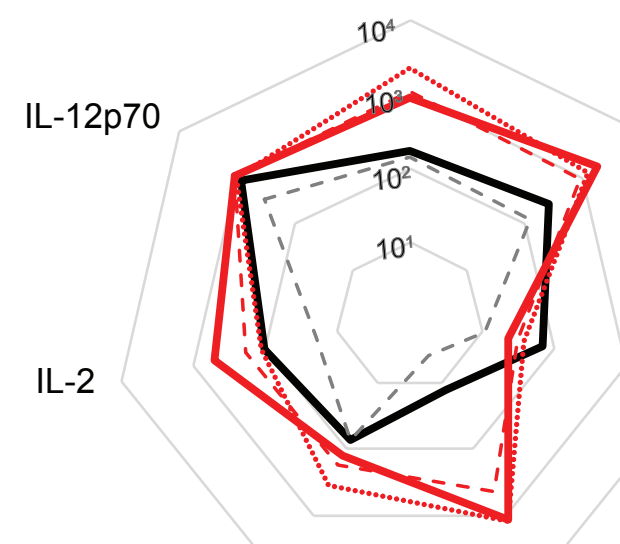

IL-10

IFN $\gamma$

\section{2hr Post-Surgery}

IL-6

IL-12p70

IL-2

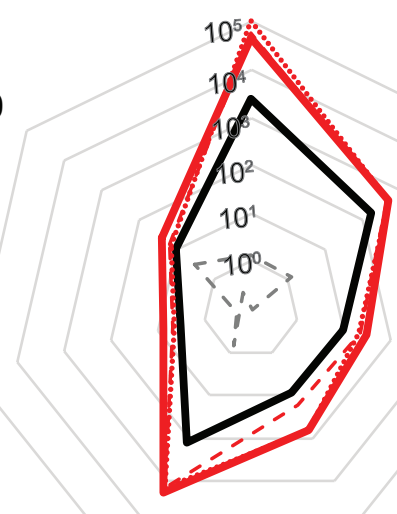

TNF

IL-10

IFN $\gamma$
TNF

IL-1 $\beta$

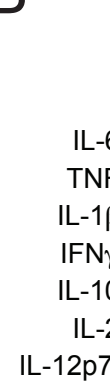

D
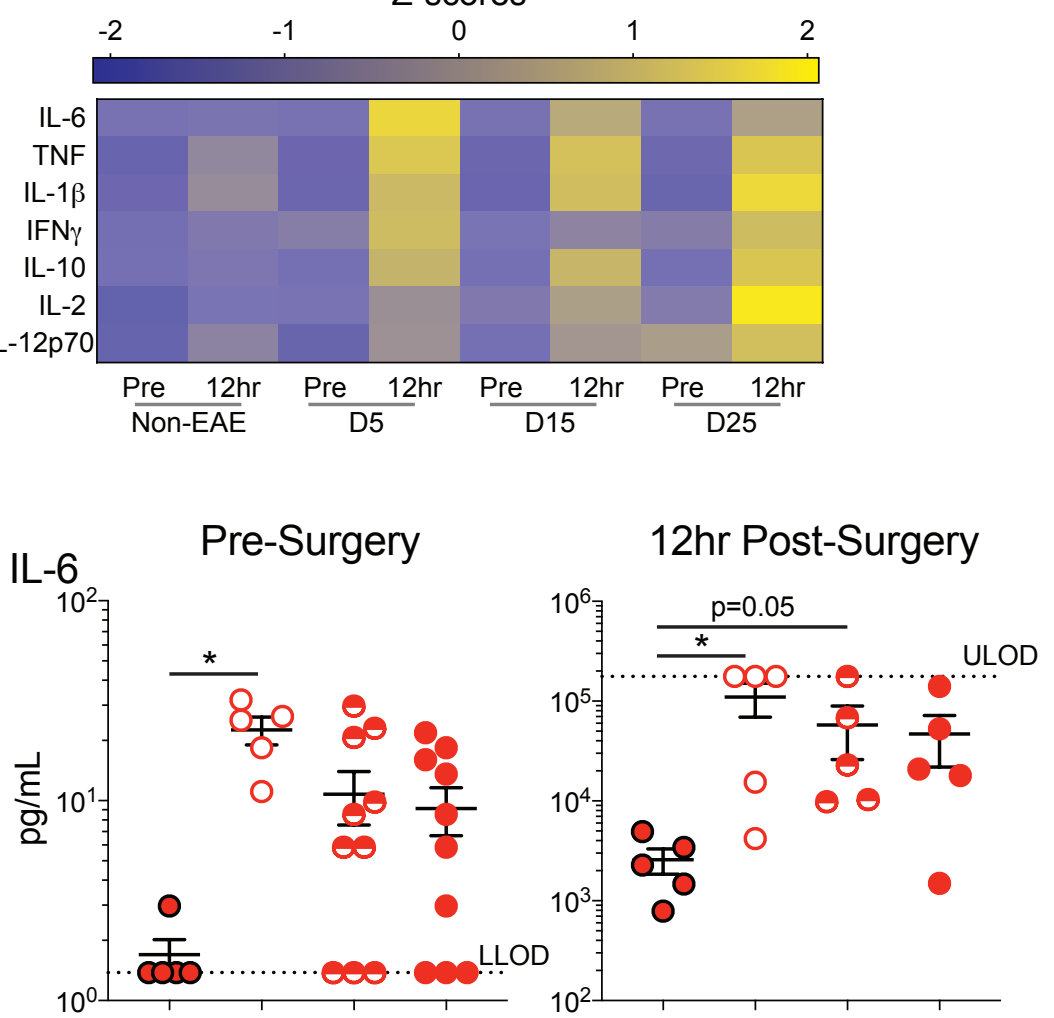

TNF

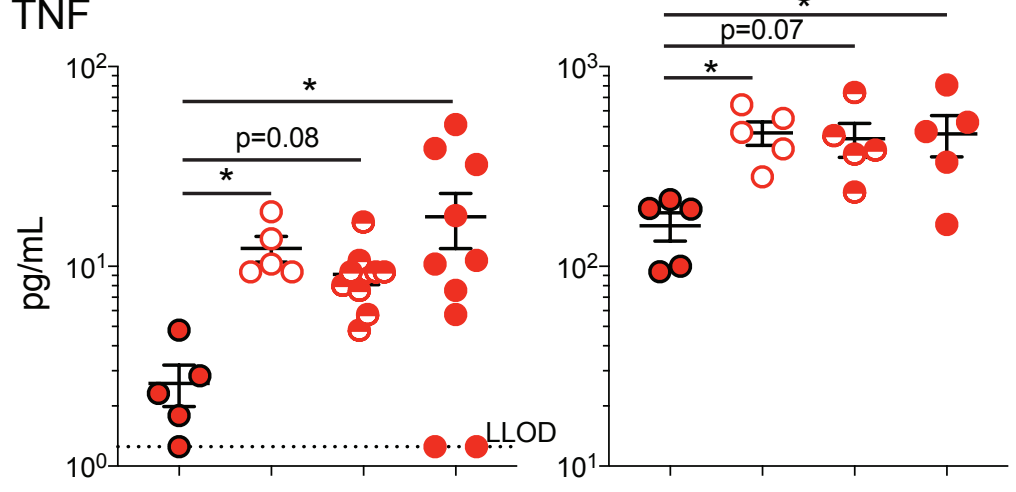

IL-1 $\beta$

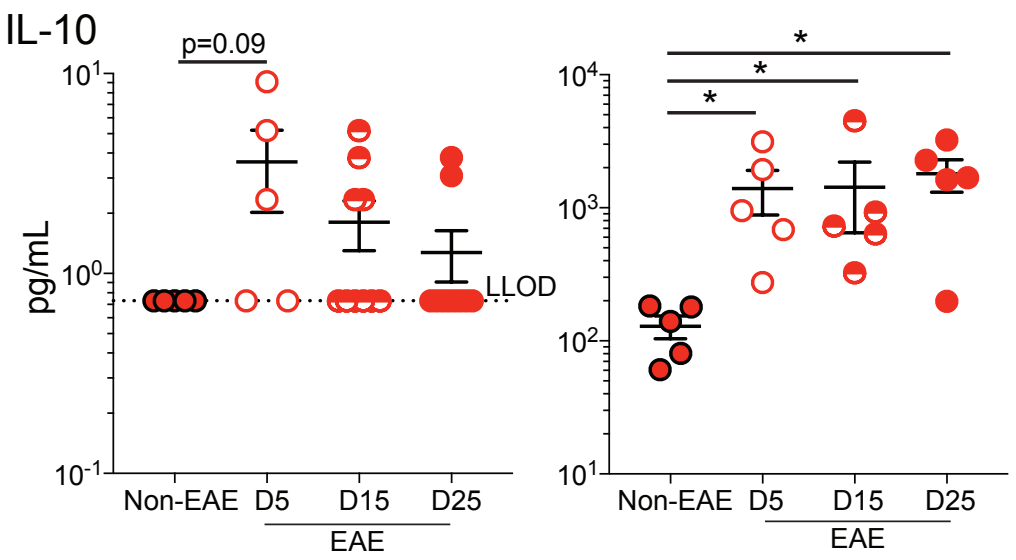


Figure 4

bioRxiv preprint doi: https://doi.org/10.1101/2021.07.06.451335; this version posted July 8, 2021. The copyright holder for this preprint (which was not certified by peer review) is the author/funder, who has granted bioRxiv a license to display the preprint in perpetuity. It is made

A available under aCC-BY 4.0 International license.

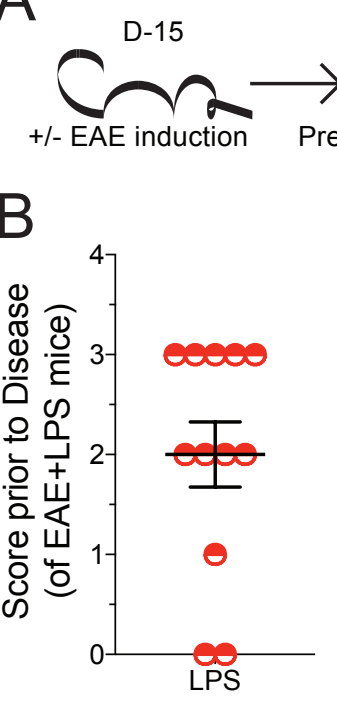

D0

$12 \mathrm{hr}$

E

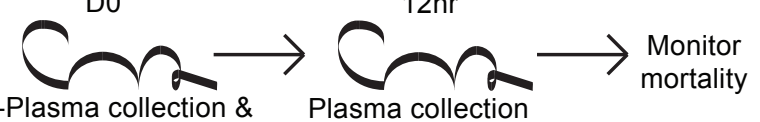
LPS challenge

C

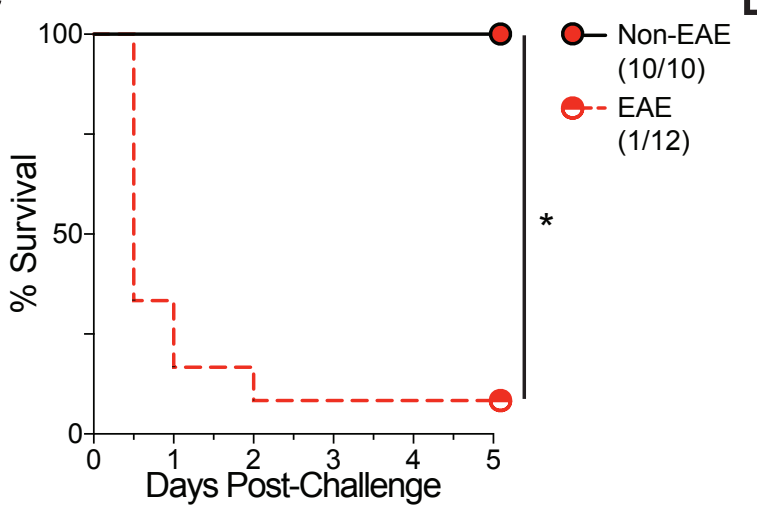

D
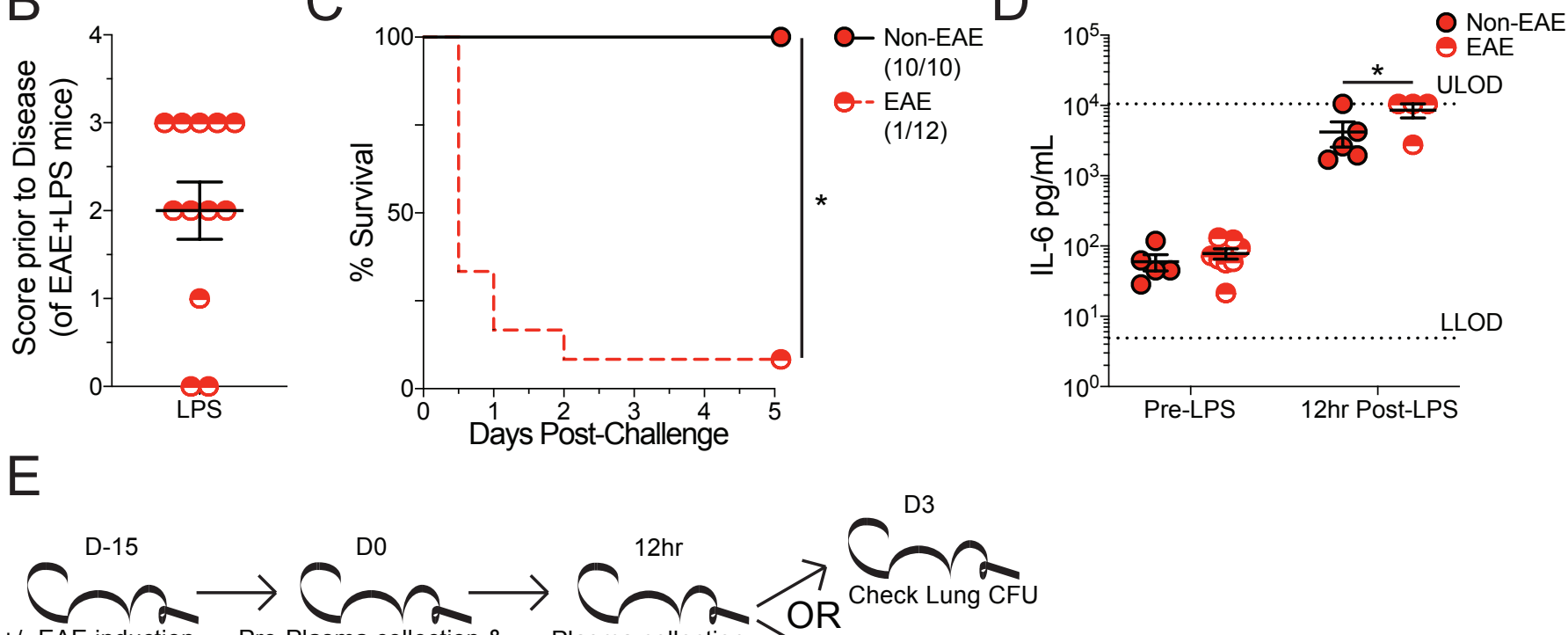

D3

+/- EAE induction

e-Plasma collection \&

S. pneumoniae inf.

Plasma collection

G

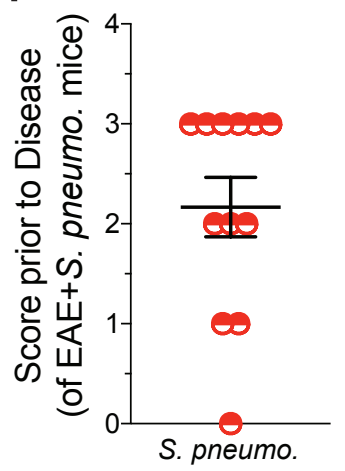

I

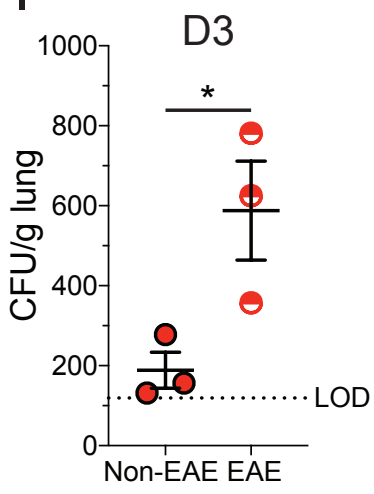

$\mathrm{H}$

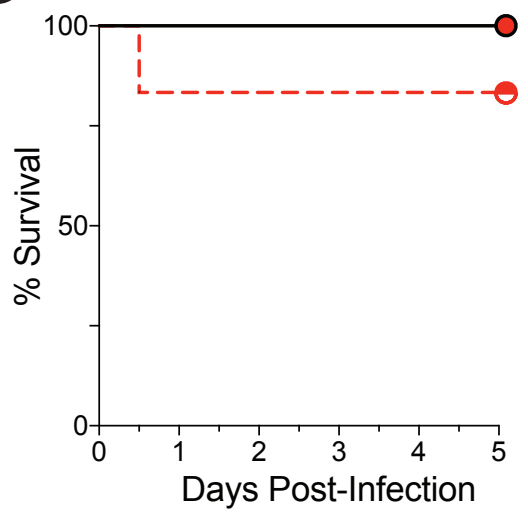

O- Non-EAE

$(6 / 6)$

- - EAE

(7/9)

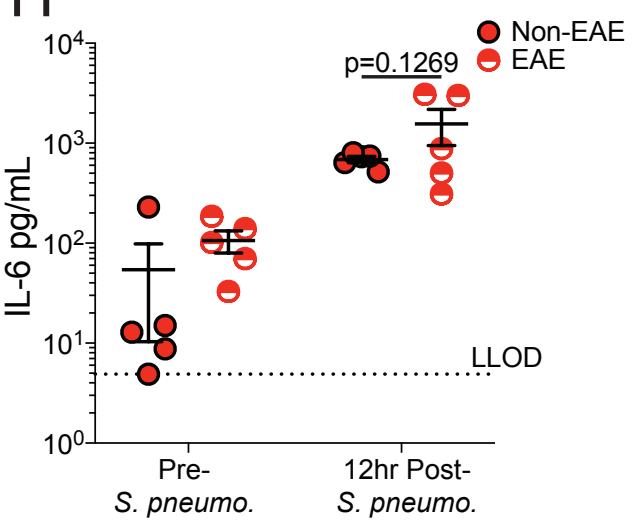


Figure 3-figure supplement 1

bioRxiv preprint doi: https://doi.org/10.110/2021.07.06.451935; this version posted July 8, 2021. The copyright holder for this preprint (which was not certified by peer review) is the author/funder, who has granted bioRxiv a license to display the preprint in perpetuity. It is made A available under aCC-B B.0 International license.

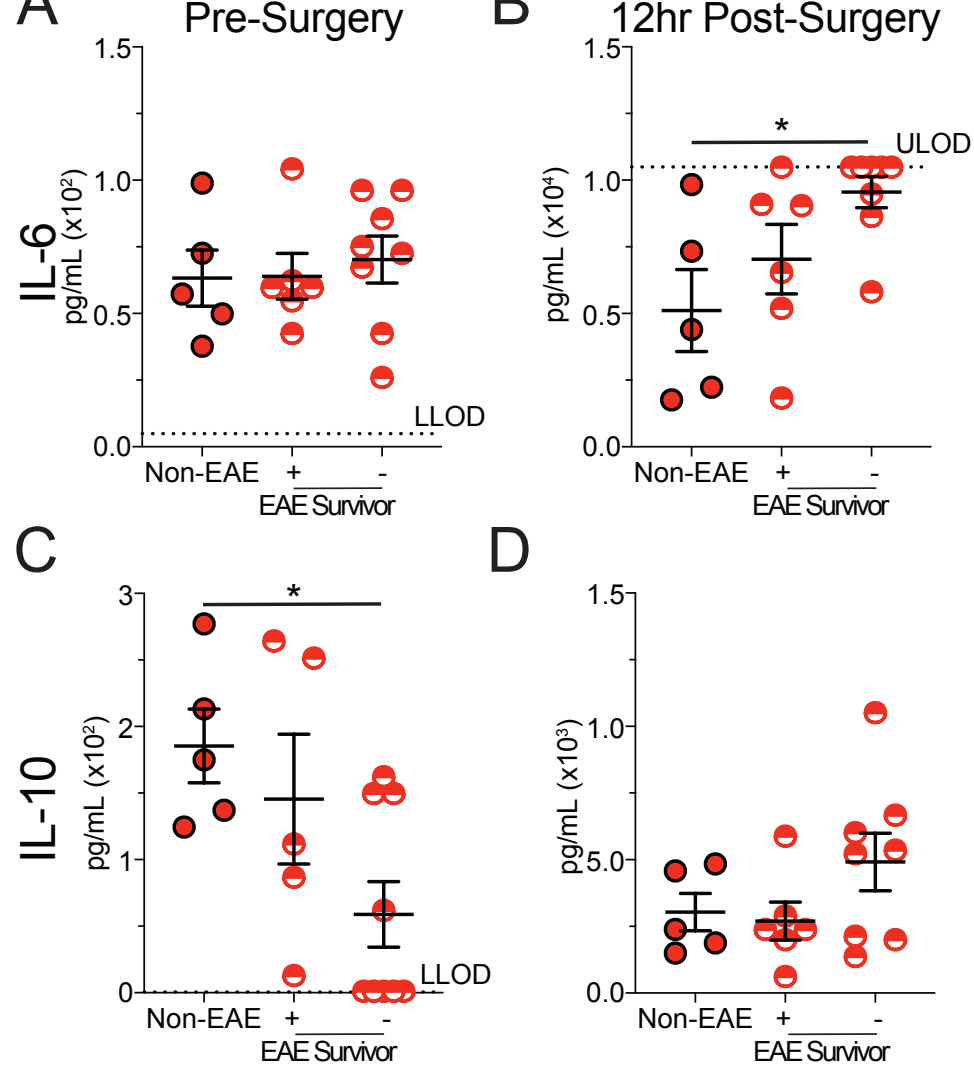

